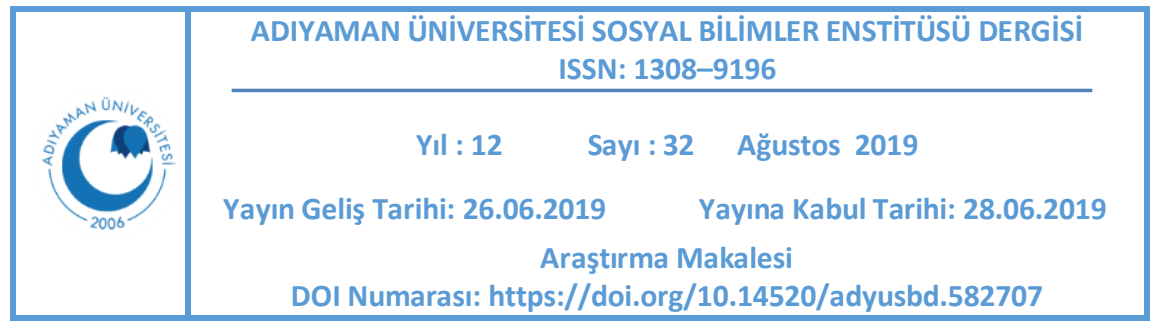

\title{
KUMRAL ADA MAVI TUNA ROMANINDA AŞK VE SAVAŞ SÖYLEMINDEN PARÇALAR
}

\section{Selami ÇAKMAKCI*}

\begin{abstract}
Öz
Buket Uzuner, Kumral Ada Mavi Tuna romanında Türkiye'nin yakın geçmişindeki çıkmazlardan olan toplumsal çatışmaları konu alır. Tuna ve sevdiği kız Ada etrafında şekillenen eserde, insanın en büyük savaşının kendi iç dünyasındaki savaş olduğu dikkati çeker. Toplumsal kırılmalar, ölümler ve aşk ilişkilerindeki hayal kırıklıklarının birbirini takip ettiği romanda, birçok kahraman toplumsal iç savaşla birlikte ruhsal bir savaş da yaşar. Roman, başkişi Tuna'nın ruhsal savaşı olarak metne yansımış olsa da birçok kahraman iç dünyasında kendisiyle, dış dünyada ise toplumla savaş halindedir.

Romanda aşk, toplumsal gerginlikler sırasında birçok insan için en büyük nefes alma imkânıdır. Romandaki birçok karakter, kültürel ve toplumsal çatışmalarından, önyargılarından aşkın verdiği imkânla kurtulur. Romanda aşk ve savaş konusunda, söylem düzeyinde güçlü parçalar metne büyük zenginlik katar.
\end{abstract}

Anahtar Kelimeler: Aşk, savaş, iç çatışma, insan, toplum.

Dr. Öğr. Üyesi, Kahramanmaraş Sütçü İmam Üniversitesi, Eğitim Fakültesi, Türkçe ve Sosyal Bilimler Eğitimi Bölümü, Türkçe Eğitimi Ana Bilim Dalı, Kahramanmaraş. selamicak23@hotmail.com 


\title{
PARTS FROM THE DISCOURSES OF LOVE AND WAR IN THE NOVEL OF KUMRAL ADA MAVI TUNA
}

\begin{abstract}
In the novel titled Kumral Ada Mavi Tuna, Buket Uzuner discusses the social conflicts in Turkey, one of the predicaments in the country's recent past. In the work that is shaped around the protagonist Tuna and Ada, the girl he is in love with, it is notable that the biggest war is the one in people's inner worlds. In the novel where social fractures, deaths and disappointments in love affairs follow each other, many characters experience a mental war. The novel was textualized as the mental war experienced by Tuna, many of the characters are at an internal war with themselves and at an external war with the society.

In the novel, love gives many people a breathing space during times of social tension. Love enables many characters in the novel to be rescued from cultural and social conflicts and their prejudices. Strong expressions of love and war enrich the text significantly.
\end{abstract}

Keywords: Love, war, inner conflict, human, society.

\section{GíRiş}

Buket Uzuner, Kumral Ada Mavi Tuna romanını 1997 yılında yayınlar. Roman iki ana olay ekseninde kurgulanmış ve her iki olay da farklı zaman dilimleri içerisinde gerçekleşmiştir. Ada ile Tuna arasındaki aşk hikâyesinin anlatıldığı birinci olay, Tuna'nın beş yaşından otuz dört yaşına kadarki yaşamını kapsar. íki ana olaydan diğeri olan toplumsal iç savaş ise yedi aylık bir zaman dilimini kapsamaktadır. Ada ile Tuna'nın aşkının konu olduğu olay geriye dönüş tekniği ile metne yansırken, toplumsal iç savaşla ilgili bölümler kronolojik olarak gelişir. Yazar, romanında hakim ve kahraman anlatıcı şeklinde iki bakış açısına yer verir. Kahramanları kültür seviyelerine göre konuşturan Uzuner, böylece anlatısında inandırıcılığı artırmış olur. 
Aşk ve savaş, romanda dikkati çeken en belirgin iki konudur. Bu bağlamda romanda aşk ve savaş söylem düzeyinde güçlü parçalar barındırmaktadır. Olay örgüsünde gerek savaşın gerekse aşkın, zaman olarak Salı günü ile ilişkisi önemlidir. Romanın ilk bölümünün "Salı sabahı" ile başlaması bu günün önemini ortaya koyar. İki ana olaydan biri olan iç savaş "Salı sabahı" başlayıp tekrar bir "Salı sabahı" sonlanır. Salı, Tuna'nın en sevmediği gündür, çünkü Tuna'nın hayatına damga vuracak iki önemli gelişme Salı günü gerçekleşir. Salı, hem Aras'ın öldüğü gün, hem de iç savaşın başladığı gündür. Ada, yine bir Salı günü Aras'ı ölümüne ilişkin açılan mahkemede beraat eder. Dolayısıyla Salı'nın Ada ve Tuna'nın hem iç hem de dış savaşında büyük rolü vardır. Savaşın hem kişisel ve hem de toplumsal boyutta ele alındığı Kumral Ada Mavi Tuna romanında Ada ve Tuna başta olmak üzere birçok kahramanın “içerideki savaş(ının) dışarıdaki savaştan her zaman daha kötü"(Phillips, 2017:65) yaşandığını söylemek mümkündür.

Kumral Ada Mavi Tuna romanında postmodern izler de yoğun bir şekilde görülür. Gerçek ile rüyanın iç içe olduğu eserde özellikle iç savaşın anlatıldığı bölümler yine gerçekle rüyanın çatışmasından doğan bir "giz"in etrafında şekillenir. Romanın başkişisi Tuna'nın iç savaş sırasında yaşadığı gerçek ile rüya arasındaki sıkışmışlığına çoğu zaman okur ortak edilir. Gerçek denilen yerde rüya, rüya denilen yerde gerçek belirir. Postmodern romanlarda "Gerçek ve düş ayırt edilemez, dil bir yanılsama aracı olarak kullanılır, masalsı, karmaşık bir hale sokularak 'giz' duygusu sürekli beslenir." (Tosun, 2014: 77). Uzuner, romanda okuru bir oyun içine çekerek yer yer bu savaşın gerçek, yer yer de bir kâbus olduğunu gösterir. Böylece romanda okur gerçek ile düş arasında sıkışır. "Gizem postmodern romanların en önemli ögelerinden biridir." (Narlı, 2015: 43) Yazar bilinçli bir şekilde kurgunun içine gizem unsurunu da yerleştirerek metinde "merak" öğesini sürekli canlı tutar. 
Postmodern eserin en önemli özelliklerinden birisi de metinlerarası ilişkidir. Metinlerin birbirinden çok da ayrı olmadığı, her metnin daha önce yazılan metinlerden izler taşıdığı görüşüne dayanan metinlerarasılık, Uzuner'in romanının da özelikleri arasındadır. Metinlerarasılık yoluyla roman; sinema, tiyatro, müzik, fotoğrafçılık, şiir ve roman birçok sanat dalının bir kesişme noktası haline gelir. Kumral Ada Mavi Tuna romanında bölüm başlarındaki epigraflar ve metnin içerisinde yer verilen başka sanatçıların metinleri ile eser büyük bir zenginlik kazanmıştır. Bölümler halinde yazılan romanda, her bölümün başında Descartes'ten Fuzûlî ve Şeyh Galib'e, Dante'den Nietzsche, Freud ve Nazım Hikmet'e kadar yerli ve yabancı sanatçılardan alınmış epigrafların içeriği, romanın ilgili bölümlerindeki olayların içeriğiyle örtüşmektedir.

\section{AŞKIN BIN BIR ÇEŞIDI VARDIR}

Edebiyatın en güçlü temaları arasında olan aşk, Kumral Ada Mavi Tuna ${ }^{\dagger}$ romanının da merkezindeki en önemli temadır. Şahıs kadrosu bakımından zengin bir kadroya sahip olan roman, birden fazla aşk öyküsüne sahiptir. Romanın kurgusal düzleminde en çok dikkati çeken aşk ilişkisi Tuna ve Aras adlı iki erkek kardeşin Ada adlı bir genç kıza duydukları aşktır. Bu aşk üçgeninde Tuna Ada'yı, Ada ile Aras ise birbirlerini sevmektedirler.

Ada, Tuna'nın yaşadığı Kuzguncuk'a sonradan yerleşmiş bir ailenin kızıdır. Tuna'nın, bir gün Ada'nın oturduğu köşke gidip köşkün bahçesinde onunla tanışması aşk hikâyesinin başlangıç noktasıdır. Henüz beş yaşında olan Tuna, yedi yaşındaki Ada'yı köşkün bahçesinde ilk gördüğünde Ada bir taşla konuşmaktadır. Onun taşla konuşması, daha sonraki iletişimsizliklerinin sanki bir habercisidir. Ada, taşla konuştuğu sırada birden Tuna'nın varlığını fark edince ona kendi ismini söyler.

\footnotetext{
+ Metindeki alıntılar, romanın Everest Yayınları'ndan çıkan 57. basımına aittir.
} 
“Ayağa kalktı, beni süzdü. Biraz düşündü.

"Ada" dedi.

"Efendim" diye sordum bön bön bakarak.

"Ada" dedi yeniden."(s.20)

Karşısındaki bu "bal gözlü kumral kız"ı görünce adeta büyülenen Tuna, kendisine bir isim ararken birden bir çiklet adı olan "Mabel" ismi aklına gelir. Tuna, güzelliğini "anlatmak için sözcüklerin yetersiz kaldığı, ancak mecazlarla, metaforlarla ifade edilebilecek" olan bu kızı elinden kaçırmak istemediği için gerçek ismini söyleyemeyerek böyle "gizemli ve albenili" bir isim seçmiştir. "Mabel" ismi Ada'nın da oldukça hoşuna gider. Mabel, üzerinde gülümseyen zenci bir kız resminin olduğu bir cikletin adıdır. Tuna, çikletin ambalajındaki gülümseyen kızı, derin bakışındaki gizemi ve hüznünden dolayı Ada'ya benzetmektedir. O günden sonra Ada, kimsenin olmadığı yerlerde Tuna'ya Mabel diyecek ve bu onların arasındaki ilk tanışmadan kalan ufak bir sır olarak kalacaktır.

" 'Ben sana Mabel diyeceğim bundan sonra,' dedi. 'Mabel adı sana çok yakışıyor.'

\section{(..)}

Köşkün bahçesinde tanıştığımız o günden sonra Ada beni daima Mabel diye ünledi. Bunu ikimizden başkası bilmez. Ada, bana sadece ikimiz yalnızken Mabel diye seslenir. Mektupları Mabel diye başlar."(s. 23)

Tuna, bütün yaşamına damgasını vuracak olan bu kumral kızı ilk gördüğü anda ona aşık olmuştur. Bu ilk görüşteki aşkta göz, duygusal çekimin başlamasını sağlayan en güçlü imgedir. "Bakış, en güvenilir ve en asil kabul edilen duyum olarak'(Lupton, 2002: 60) sözcükler olmadan iki öznenin karşılıklı konuşmasını 
sağlamıştır. Tuna, bu ilk karşılaşmada Ada'nın bal rengi gözlerinin çekiminde kaldığını şöyle dile getirir:

(...) Bazen yeşil, bazen mavi-sarı dalgaların kıvrılarak sürekli hareket ettiği kumral gözlere kilitlenip kaldım. Yaşantımda ne daha önce, ne daha sonra bu kadar kumrala boyanarak bu kadar kumrala boyanarak doğmuş başka bir kız gördüm ben! Ve o andan sonra hiçbir kadının gözleri onunkinden daha derin ve güzel olmadı!"(s. 20-21)

Tuna'nın Ada'ya aşık olduğu bu sahne gerçek bir aşk sahnesidir. İlk karşılaşma anında karşılıklı büyülenmeyi başlatan, kelimelerin hiçe sayıldığı anlam dolu olan ilk bakışta göz imgesi aşkın kaynağı olmuş ve aşk arzusu başkasının üzerinde billurlaşmıştır. Çünkü aşk "Bir çift kara göze esir olmaktır...” (Gülsu; 2011: 159). Gözlerde başlayan aşk duygusunun Tuna'nın dünyasında yarattığı sarsıntı, ne yazık ki Ada'nın dünyasında pek geçerli değildir. Ada, Tuna'yı sevmektedir, ancak o Tuna'nın ağabeyi Aras'a âşıktır. Ada ile Aras arasındaki aşk da bir “yıldırım aşkı"(s.198) şeklinde gelişmiştir.

Ada ile Tuna arasında yaşanan tanışma olayının gelişme biçimi, halk hikâyelerindeki aşk olayının yaşanma biçiminden izler taşır. Çünkü halk hikâyelerindeki aşığın sevdiği kıza sevgisini ispatlaması için verdiği sınavın bir benzeri Ada ile Tuna arasında yaşanır. Ada, ilk tanışmada Tuna'nın bundan sonra kendisiyle oyun oynayabilmesi için üç kertenkele kuyruğunun suyunu içmesini ister. O böyle bir sınava zorlandığı sırada kardeşini kurtarmaya gelen Aras, Ada'yı görünce birbirlerine aşık olurlar. İkili arasındaki bu aşkı ilk fark eden ise ne yazık ki Tuna'dır.

"Ada, Aras'ı görünce çarpılmıştı ve ne yazık ki bunu onlardan önce ben anlamış ve ben görmüştüm. İçimde kocaman bir şangırtı koptu, çocukluğumun camları tuz buz oldu. Kimse iç kırıklık seslerimi duymasın diye haykırdım: 
“Durun durun! Ben içerim bunu, tamam mı?"(s. 81)

Tuna'nın kertenkele kuyruğunun suyunu birden içmek istemesi, Ada'ya olan aşkını ispatlamak amacı taşır. "Aşkın binbir çeşidi"nden biri seven kişinin sevdiğinden aynı karşılık görememesidir. Doğuştan duygusal bir kişilik olan Tuna, birkaç dakika içerisinde aşkın verdiği umut ile onun yaşattığı hayal kırıklığını bir arada deneyimler. "Filmin asıl oğlanıyla asıl kızının sonunda karşılaşmış oldukları"nı gören Tuna bu aşk öyküsünde kendisinin o andan itibaren hep ikinci planda kalacağını fark eder. Aldanma ve düş kırıklığı aşkın vazgeçilmez kaderidir. Aşk arzusuna yanıt beklerken, sevilmediğini anlayınca hayâl kırıklığı yaşayan Tuna, boşlukta yüzmeye başlar ve artık aşk kendisi için bir imkânsızlığa dönüşür. Çünkü Tuna için Ada, bir yaşama sevinci olduğu kadar hayata tutunabilmek için bir sebeptir. Ada'yı hayatının neşesi olarak gören Tuna, "Birinin küçük erkek kardeşi, öbürünün Mabel'i"(s.226) olmasından dolayı bu aşktaki imkânsızlık yüreğini daha çok acıtmaktadır. Tuna, Ada'nın bakışlarında okuduğu; "yanında olacağım, seni anlayacağım, ama sana ait olmayacağım" (s. 232) düşüncesi bu aşkın imkânsızlığını iyice anlamıştır. Zamanının çoğunu köşkte Tuna ile geçiren Ada ise Aras'a aşık olmakla beraber Tuna'yı hep korumaya çalışmakta ve bir öğretmen gibi onun ufkunu açmak istemektedir. Tuna'ya olan sevgisinde şefkat duygusu ağır bastığından onu incitmemeye özen gösterir. Ancak Tuna, Ada'nın kendisine olan ilgisini genç kız tarafından sevildiğinin işareti olarak yorumlamaktadır.

"Ben çok mutluydum. Ada'yla oynamak büyük keyifti. Cömertti, adildi ve hayal gücü genişti. Çok oyun biliyordu, genel kültürü yaşının fazlaca üstündeydi, çok oyuncağı vardı ve çok güzeldi. Bal renginde, bal gibi bir kızdı! Tanrım nasıl da akıyordu o bal gözleri içime tatlı tatlı..." (s. 111)

Ada'nın, Tuna'nın sevgisini görmezden gelerek Aras'ın duygusal çekim alanına girmesinde, Aras'ın güçlü kişiliği etkilidir. Ada ile Aras'ın birçok yönden 
birbirlerine benzemesi onların birbirlerine aşık olmalarının temel sırrıdır. "Psikologlar kimin kime aşık olduğu konusunda yaptığı çalışmalarda kişilik özellikleri, zekâ, değerler gibi etkenlerin olduğunu fark etmişlerdir."(Pines, 2003: 35). Aras, "zekâsı ve cesaretiyle" Ada'nın duygusal çekim alanına girmiştir. Ada da "Yaratılışı, karakteriyle birlikte taşıdıkları ve yetişme tarzı, (...) Duruşu, yürüyüşü, gülüşü, hatta ellerinin hareketleri bile bana bir prensesi çağrıştır(an)” (s. 118) Aras'ın hayranlığını kazanmıştır. Aras, adeta kendisini büyüleyen "bal renkli kızın üzerine çakılmıştır"(s.199). Her ikisi de tuttuğunu koparan, hırslı ve güçlü karakterlerdir. Ada ve Aras'ın kişilik olarak birbirlerine benzerliklerini fark eden yine Tuna'dır. Hassas, içli, romantik ve biraz da nazlı bir erkek olan Tuna'ya göre, kızların ağabeyini sevme nedeni, onun güçlü, zeki ve kararlı biri olmasıdır. Kibirsiz ve sakin davranışlarıyla çevresindeki kızları baştan çıkaran Aras'ın gözü Ada'dan başkasını görmemektedir. Onların birbirlerine duydukları aşkta bir ulaşılmazlığı elde etmiş olmanın taşıdığı bir gurur da vardır.

"Asla çapkın bir delikanlı olmadı Aras. O, taa en başından beri Ada'ya sevdalanmıştı. Ada'nın eşi güç bulunur vurgundu ağabeyim. Kimsenin görmediğini sandığı kaçamak anlarda Ada'nın ela gözlerine bakışlarını nasıl unutabilirim? Onun Ada'ya verdiği değer, bir erkeğin bir kadına ne kadar çok âşık olabileceğinin uç örneklerinden birisi olmuştur benim gözümde”(s. 200).

Tuna'nın Ada'yla ilişsilerindeki sakinliğin aksine, Ada ve Aras ilişkisi sert, yıpratıcı ve daha çekişmelidir. Her ikisinin de yaşıt olması ve aynı sınıfı paylaşmaları, birbirine karakterce benzeyen bu iki kahramanı, amansız bir rakip haline getirmiştir.

“(..) Fakat onlar birbirleriyle didişmeye, birbirlerini yorgun düşürmeye bayılıyorlardı. Bu nasıl bir kişilik yapısıdır ki, ben onları izlemekten bile bitap düşerken, o ikisi hiç bıkmadan yarışı sürdürebiliyorlardı? Birbirlerini yenmekten aldıkları zevk kadar, yenilmiş olmanın yarattığı bir sonraki didişmeye hazırlık 
safhasından da ayrı bir haz duyduklarını hissediyordum. Tam birbirlerinin dişine göre yaratılmışlardı!'”(s. 159-160)

Tuna, ağabeyi Aras ile Ada'nın birbirlerine aşık olduklarını bilmesine rağmen umutsuzluk içinde sevmeye devam eder. Bu durumu kabullense de içindeki kıskançlık her geçen gün büyür. "Kıskançlık, aşkta doğan ve sevilen kişinin başka birini yeğlemesi korkusunun ürünü olan duygu(dur)."(Barthes, 2012: 134). Tuna'nın kıskançlığı, sevileni sürekli canlı tutarak aşk arzusunun yok olmasına engel olan bir duyguya dönüşmüştür. $O$, Ada ve Aras'ı izlerken onların aşklarındaki yüceliğe bile imrenerek bakar.

"Birbirlerine baktılar. O ilk aşkın daha hiç kırılmamış düşleriyle baktılar birbirlerine. Çok güzel baktılar birbirlerine. Itiraf etmeliyim ki, kıskanmanın ötesine uçacak kadar sevdim o bakışlarını..."(s. 222)

Tuna, Ada'ya olan duygularını, aşkının büyüklüğünü düşünerek kimin Ada'yı daha fazla sevdiğine ilişkin Aras ile kendisi arasında zaman zaman karşılaştırma yapar. "Aras'ın Ada'yı, benim sevdiğim gibi sevmiş olduğuna hiçbir zaman inanmadım."(255-256) diyen Tuna'ya göre Ada'yı gerçekten Ada olarak seven tek kişi kendisidir.

Ada ile Aras aşkı, Aras'ın trajik ölümüyle sonlanır. Aras'ın liseyi bitirdiği ve üniversite sınavının sonuçlarını beklediği günlerde Tuna, Aras ve Ada, Fethi Paşa Korusu'na giderler. Burada Tuna, tesadüfen Aras ve Ada'yı uygunsuz bir şekilde görünce Aras titreme nöbetlerine girer. Eve döndükleri sırada Aras kendisini ispatlamak istercesine ve Ada'ya sahip olmanın verdiği gözü peklikle akşamüstü denize girmek ister. Tuna'nın tüm ısrarlarına aldırmayan Aras denize atlar, ancak denizden bir daha çıkamaz. Ada ile Aras arasındaki bu aşk öyküsü Aras'ın trajik ölümü ile tüm neşesini ve heyecanını kaybeder. Hem Ada'nın ve hem de Tuna'nın beyni o kara gecede çakılı kaldığından kendilerini o gecenin etkisinden 
yıllarca kurtaramazlar. İkisinin de bilinçaltında oluşan korku ve kaygılar o trajedinin yaşandığı günün etkisinde kalmış olmalarıdır. Aras'ın ailesinde ruhsal ve bedensel yıkımlara sebep olan bu trajik ölüm olayından sonra Ada, günlerce hastanede kaldıktan sonra eve döner ancak kendi ailesi ve Tuna dışında kimseyle görüşmez. Illkbahar geldiğinde ise annesi ile Amerika'ya gider. Tatillerde köşse dönse de artık eski Ada değildir. Kaçış, Ada'nın problemlerini çözmemiş, ona tekrar o eski, mutlu günlerini geri vermemiştir. Ada yarım bıraktığı lise diplomasını ve sanat koleji diplomasını alıp fotoğraf sanatçısı olarak Amerika'dan Türkiye'ye döner, ancak Kuzguncuk'taki köşke yerleşmez. Beyoğlu'nda bir stüdyo ev kiralayan Ada'nın köşke yerleşmek istememesinin temel nedeni, Aras'ı unutmak istemesidir. "Mekân, peteklerinin binlerce gözünde, zamanı sıkıştırılmış olarak tutar." (Bachelard, 2013: 39). Ada, içinde Aras'la ilgili hatıraları barındıran köşkün kendisini huzursuz edeceğini düşünmektedir.

Bu trajik ölüm olayının etkisiyle ağır bir travma yaşayan Tuna ve Ada'nın iç dünyalarında çetin bir mücadele yaşamaya başlarlar. Bundan sonra Ada'nın, Aras'ın ölümünden dolayı tuttuğu yas ve Tuna'nın Ada'ya kavuşma kaygısıyla ikisi de acı çekerek yaşamlarına devam edeceklerdir. Her ikisi de yıllarca Aras'ın öldüğü günde yaşayan bir düşünceyle kendi iç dünyalarında yaşayacaklardır. Yazar, roman kahramanlarından şair Doğan Gökay’a ait olan aşkın acı verdiğine dair bir dizeyi sık sık tekrarlayarak böylece aşkın getirdiği mutluluğun yanında yaşattığı acıya da belirginlik kazandırır.

"'Bak, aşkın bin bir çeşidi vardır.' Dedim istiklal Caddesi'nde tünele doğru yürürken.

'Ve her çeşidi de acıtır! Doğan Gökay'ın şiiri di mi?' "(s. 351) 
Boşlukta kaldığını hisseden Ada'nın, Tuna'ya sarılmaktan başka çaresi yoktur. Bu nedenle Aras'ın ölümünden sonra Tuna'ya bakışında bazı değişiklikler olur. Ada bir aşktan öbürüne geçerek yine aşk duygusunun içinde kalmak ister. Genç kız, Aras'ın yasının verdiği ıstırabı yenmek için adeta başka bir özneyi onun yerine koymak ister. Bu, Ada için acıyı bastırmanın başka bir yoludur. "'Sen... aramızda hep bir engel olduğunu sandığın Aras'ın hiç olmadığı ve olamayacağı birçok şeyimsin benim... Sen olmazsan... Bunu bilmelisin... Sen olmazsan çok eksilirim ve artık buna dayanamam Tuna!'” (s. 363) diyen Ada, uçurumdan yuvarlanırken tutunacağı tek dal olarak Tuna'yı görmektedir. Ancak Ada Tuna ile evlenmekten korkmaktadır. Çünkü Ada, "onu evlenmek istemeyecek kadar çok sev(mektedir)." (s. 449). Tuna'yı çok sevmesine rağmen onu da kaybetme korkusu taşımaktadır. O, etrafta söylenilen dedikoduların da etkisiyle kendisinin uğursuz olduğu inancına kapılmıştır. Ada, Tuna'ya olan sevgisinin ve onunla yapacağı evliliğin bu acının doğurduğu boşluğu dolduramayacağını anlayınca ondan uzak durmaya karar verir. Böylece Aras'ın ölümü, geride kalan Ada ve Tuna'yı birleştirmez aksine ayırır. Aras'ın ölümünün verdiği ıstırabın pençesinde yaşamlarını sürdüren Ada ile Tuna arasında şu diyalog gerçekleşir:

"'Seni sık sık düşündüm Tuna. Özellikle yurt dışındayken... Seninle nereye kadar gider, nasıl gideriz diye... Ama...'

'Ama ne?'

'Ama hep korktum!'

'Delisin sen. Neden korktun, neden korkuyorsun?'

'Seni yitirmekten Mabel! Elimi sürdüğüm şeyi yitiriyorum. Sevdiğim şeye yakınlaşırsam kaybediyorum onu...' (...) 'Hayır, hakkımda çıkartılan 'uğursuz kız' söylentilerini alıp giymedim üstüme ama çok küçüktüm ve bunlardan fena 
etkilendim. Öyle zamanlarım oldu ki Mabel... Aras’ı ben öldürdüm diye inanmaya ve kahrolmaya başladım. Gerçekten inandım buna ben."(s. 364-365)

Görüldüğü gibi Ada'nın iç dünyasındaki savaşı dış dünyadan daha çetin geçmektedir. Onun düşündüğü bütün çözümler engelelri de birlikte getirmektedir. Geçmişten uzaklaşamamak genç kızın en büyük problemidir. “Freud, bütün içgüdülerin geçmişe eğilimli olduğunu öne sürer."(Bauman, 2012: 33). Geçmişin dışına çıkamayan bir özne olarak Tuna'nın da Ada gibi zihni geçmişte takılı kalmıştır. "Zerdüşt, 'zamanın geriye doğru akması huzursuzluğa neden olur.' "(Alberoni, 1990: 21) der. Geçmişte yaşayan Ada için şimdinin bir değeri bulunmamaktadır. Ada, bir bakıma melankolik bir kişiliğe kapılmıştır. “Melankolik kişi geçmişte yaşar.(...) bellek geçmişe saplanmıştır. Dış dünyaya ilişkin ses ve görüntü silikleşmiştir. Egemen olan geçmişin sesi ve görüntüleridir."(Korkmaz, 2018:418). Tuna, Ada'nın kendisine yaklaşımında hep bir sevgi görse de geçmişi unutamadığından onunla asla birlikte olamayacağını bilmektedir. Adanın kaçışı, Tuna tarafından fark edilince kendisi de Ada'dan kaçmaya başlar. Onun, Meriç'le evlenmeye karar vermesi aslında Ada'dan kaçmak isteğinden kaynaklanır. Tuna, ağabeyinin ölümünden dolayı geçmişin acılarıyla birlikte bir de Ada'yla mutlu bir gelecek kurmanın umutsuzluğuyla karşı karşıyadır. "Umutsuz kişi olası tüm geçmişi bir şimdi gibi taşır"(Kierkegaard, 2010: 25). O, bu umutsuzluğu yok edemediği gibi bir de kararsızlığın içindedir. Tuna, annesinin Meriç ile evlenmesi için ısrar etmesi üzerine, Ada'yla konuşmak ve artık hayatlarına bir yön vermek ister. Böyle bir konuşma için fırsat kollayan Ada, onu daha önce Aras'la birlikte buluştukları Baylan Pastanesi'ne çağırır. Ada, bu konuşmada içinde yıllardır gizlediği duygularını ilk kez açığa vurur:

"Sen hiç kimsenin olamayacağı kadar çok şeyimsin benim... Yüreğimde sana ayrılan yer herkesinkinden büyük. Yalnızca bir arkadaş, bir kan kardeş, bir sırdaş, birçok yakın dost değil, bir büyük sevgisin sen... Yanında sonsuz şımarabileceğim 
ve hala kaybetmekten korkmayacağım tek kişi... Yani biraz annem, biraz babam, hatta hiç görmediğim dedem, belki hiç doğmayacak oğlum... Sonra daimi hayranım ve tabii dokunulmamıs sevgilim... Sen benim masumiyetimsin Tuna..." (s. 363)

Ada'nın, Aras'ın öldüğü günden kalan korkuları bu birlikteliğin önünde engel olarak durmaktadır. Aras’ın ölümünden dolayı insanların kendisini suçlaması geleceğe korku ile bakmasına neden olduğu gibi gelecekle ilgili kararlarında da bir engeldir. $O$, suçluluk duygusundan dolayı ruhunun hapsolduğu duvarları yıkamamıştır. Tuna, Ada'nın yeni bir hayata adım atamamasının sebeplerini aramak için Ada'nın bir gün yatak odasına girdiği zaman anlar. Onun yatağının başucunda kendisi ve Aras'ın çocukken birlikte çektirdikleri fotoğrafı görünce, Ada'nın bu mahkûmiyetini daha iyi anlar.

"Tanrım, bu yetişkin kadın, yatağının başucundaki iki çocuğun fotoğrafıyla yaşıyordu hâlâ! iki çocuk! Yaşamını bu biri çoktan ölmüş, öbürü beceriksizce ortalarda dolaşan iki oğlan çocuğu yüzünden yaşayamıyordu Ada! Aras'ın hayaletiyle, benim kararsızlığım bu kızın büyümesine izin vermiyor, üstelik onu özgür de bırakmıyordu(k). Ada, kalbini Aras'ın öldügü yaşa kilitlemiş, bir daha açamıyordu. Tanrım, bu kız bizi bu kadar çok seviyordu ve bu sevgi yüzünden aslında hiçbirimiz hayatımızı yaşayamıyorduk!” (s. 370)

Ada'nın kendisiyle evlenmeyi düşünmediğini anlayan Tuna, bu gerçeği öğrendikten sonra gerek Ada'nın yolundan çekilerek onun kendi hayatına yön vermesini sağlayabilmek gerekse kendi dışındaki kişileri, annesi ve Meriç'i mutlu edebilmek adına evlenmeye karar verir. Hümanist biri olan Tuna, Meriç'le evlenerek kendisi dışında herkesi mutlu edebileceğini düşünmektedir. "Aşkın, sevilen kişi uğruna kendini feda etmek ve özveride bulunmaktan daha iyi bir kanıtı yoktur."(Fromm, 2008: 15). Bu evlilikle Tuna'nın aşk arzusu yok olmaz, 
ancak başka bir boyut kazanır. Çünkü o, bu evlilikle kendi mutluluğunu dışta bırakarak başkalarının mutluluğunu önceler.

"Eğer... eğer ben yolundan çekilirsem, belki Ada da kendi yaşamını özgürce yaşama gücünü bulacaktı? Eğer ben Ada'nın yolundan çekilirsem, Meriç mutlu olacaktı. Annem sevinecekti. Galiba herkese iyilik etmiş olacaktım eğer..."(s. 370)

$\mathrm{Bu}$ evlenme düşüncesi, Meriç'in Tuna'ya olan ilgisi sonucu oluşmuştur. Bu bağlamda romanda "aşkın bin bir çeşidi"nden biri de Tuna ile Meriç arasında yaşanır. Bu ikili arasındaki aşkın özelliği Tuna'nın Ada'ya olan aşkındaki imkânsızlığa benzer. Meriç, Ada'nın kuzeni ve ailevi problemlerden dolayı sık sık köşkte kalan, Ada'dan güzel olmasına rağmen Tuna'nın ilgisini çekemeyen bir kızdır. Köşkte sığıntı gibi yaşıyor olmanın ezikliği ve sessiz dünyasıyla dikkati çeken Meriç, Tuna'dan bir yaş büyüktür. Meriç, "hala ve eniştesinin yanında evlatlık gibi iğreti yaşıyor"(s.199) olmanın verdiği eziklikle beraber "varoluşuyla ilgili sorunları" olan bir genç kızdır. Meriç için aşk, bu ezikliği yenmenin ve var oluşunun onaylanmasının bir yoludur. Çünkü "varlığımıza geçerlilik kazandırmak için başkalarına ihtiyaç duyarız." (Botton, 2005: 128-129). Birçok yaşamsal eksikliği aşk yoluyla tamamlarız. "Aşk onu kucaklayarak bütün dünyayı dışarıda bırakma (...) insanın ruhuna güvenli bir sığınak bulma özlemidir."(Pamuk, 2013: 84). Bireyi motive eden aşk, var oluşumuzu onaylayan bir güç olarak Meriç'in mutlu olabileceği tek şeydir. Meriç'in Tuna'yı sevmesine karşın Tuna ona ilgisizdir. Meriç'in ona olan ilgisini fark ederek haber veren ise Ada olmuştur.

"'O çok tatlı bir kızdır Mabel ve ilk gördügü günden beri sana bayılıyor!'

Bakışmıştık Ada'yla.

'Ama o sana hiç benzemiyor Ada!' 
'Sen de Aras'a benzemiyorsun benim tatı Mabelim, ama ben seni çok seviyorum!'

Doğru söylüyordu.

Ada doğru söylüyordu.

Içimdeki bütün uçurtmaların ipleri koptu ve hepsi havaya savruldu."(s. 172)

Tuna, Ada'nın yukarıdaki sözlerinden sonra "uçurtmaların ipinin koptuğunu" ve Ada'yla kurduğu gelecek planlarının suya düştüğünü anlar. "Uçurtmaların ipinin kopması", söylem düzeyinde aşktaki çaresizliği yansıtır. Burada Ada-Tuna-Meriç arasında bir çekim ve itim yaşanmaktadır. Tuna, tutkuyla sevdiği Ada'dan sevgisine karşılık görememekte, ancak Meriç tarafından sevilmektedir. Tuna ve Meriç'in ortak yanları başkalarına âşık olan kişileri seviyor olmalarıdır. Aralarındaki fark Tuna'nın bu sevgi için bir mücadele içindeyken, Meriç her konuda olduğu gibi mücadelesini sessizce sürdürmesidir. Tuna için Meriç sadece içinde bulunduğu sorunlarından dolayı acınılacak bir kişidir. Başkalarının mutluluğu ile mutlu olabilen Tuna, aynı duyarlığı Meriç'e karşı göstermekte ve ona şefkatle bakmaktadır. Aşk, güzelliğe duyulan arzu olarak bilinse de güzellik, her zaman aşkı doğurmaz. Çevresi tarafından “Grace Kelly’ye benzetilen Meriç, Tuna'ya göre her erkeğin dikkatini çekebilecek kadar güzel bir kızdır. Ancak Kumral Ada'nın duygusal çekiminden kendini kurtaramadığı için Meriç'in güzelliği kendisi için bir anlam ifade etmemektedir. Tuna'yla evlenen Meriç'in bir de çocukları olur. Ancak birbirlerinin yüreğinin dışında kaldıklarının farkındadırlar.

"Tuna'yı uzaktan severdim. Ben onu hep uzaktan sevdim... Yani şimdi bile aslında... nasıl denir, yani, sanırım ben kocama yakın sayılmam... O da bana... Yani ben hâlâ, galiba Tuna'yı uzaktan seviyorum." (s. 425) 
Romanda "aşkın bin bir çeşidinden biri" de Musa ve Suları arasında gelişir. Ancak diğer aşk öykülerinin aksine bu ikili arasındaki aşk, insanı olgunlaştıran ve olumlu değişimleri sağlayan bir karakterdedir. İç savaşın ortasında gelişen bu aşk öyküsü, aşkın kültürel anlamda sınır tanımazlığının bir göstergesidir. Yazar, eserde farklı kültürden iki insanı bir araya getiren bu aşk ilişkisi ile ülkede yaşanılan toplumsal iç savaştaki insanların kültürel çıkmazlarına ayna tutar. Çünkü yazarın romanda savunduğu düşünceye göre aynı ülkede birlikte yaşayan insanların bir araya gelmesi için birçok neden varken, insanlar çok küçük farklılıklar nedeniyle birbirlerinden ayrılmışlardır. Dolayısıyla bu aşk ilişkisinde, sevgi insanların bütün önyargılarını yıkan bir güce dönüşür. Aşırı dindar birisi olan Musa'nın, alevi olan Suları'ya aşık olduktan sonra, düşünceleri değişir. Musa'nın düşünsel değişimi Tuna'yla aşk üzerine olan konuşmasında hissedilir. Bu konuşmada aşk, Musa'nın yeniden doğuşunu gerçekleştiren bir gerçeğe dönüşmüştür.

"'Bi tuhaf oldum ben Tuna... Çocuk gibi bi hallere düştüm. IÇim içime sığmaz, yerimde duramaz oldum.'

'Aşk kimseye lüks olmamalı Musa.'

'Yüzüme nur yağıyor onu görünce...'

'Aşk, sevdiğini her gördüğünde yeniden doğmak sevincidir.'

'Sanki bir peri, bir melek o! Cennette bir ağaç, zemzem Suları...' "' (s. 319-320)

Romanda kadınlar ile erkekler arasındaki aşk anlayışındaki farklılığa da vurgu yapılır. Aşk konusunda romanın en güçlü söylemi olarak gördüğümüz "Aşkın bin bir çeşidi vardır." Ifadesin bu farklılığı dile getiren bir söylemdir. Tuna, tüm yaşamı boyunca sadece Ada'nın aşkı etrafında dönen bir hayatı yaşarken, Ada 
aynı anda Aras'ı, Tuna'yı hatta Şair Doğan Gökay'ı farklı duygularla sever. Eserde sık sık tekrar edilen bu vurgu, Tuna'nın ve Ada'nın kurduğu cümlelere de yansır.

“Ama bir erkek yaşamı boyunca aslında bir tek kadını sever. Önce ve sonrakiler birer arayış, kaçış ve aldanıştır!"

"Bir kadın her erkeği farklı sever ve her kadın bir yaşamda pek çok erkeği birden sever. (...)

'Erkeklerin çok yönlüsü bile monotondur, bu yüzden asıl çokeşliliğe gereksinen kadınlardır! Çünkü cinsel çeşitlilik ihtiyacı insanı öldürmez ama duygusal yetmezlik öldürür!'”(s. 321, 366)

Yukarıdaki satırlarda Ada'nın vurguladığı “duygusal yetmezliğin insanı öldürmesi" aşk olmadan insanın yaşayamayacağına ilişkin bir göndermedir. Hem erkeğin hem de kadının aşka olan gereksiniminde nesneden çok, aşk duygusunun kendisi sevilir. İnsan çoğu zaman aşk nesnesini yitirmiş ola da aşk arzusu canlı kalır ve bu duygu kişiyi hayata bağlar. Kısaca kişi sevdiğini yitirse de aşk arzusunu yitirmez.

\section{IÇERIDEKI SAVAŞ DIŞARIDAKI SAVAŞTAN KÖTÜDÜR}

Kumral Ada Mavi Tuna romanında dış dünyada yaşanan toplumsal iç savaş ile bireylerin iç dünyasında yaşanan ruhsal savaş birbirine paralel ilerler. Romanda zihinlerdeki savaşın en büyüğü Tuna'nın iç dünyasında yaşanır. İç dünyasındaki savaşı kazanıp gerçeğe yüzünü dönemeyen Tuna'nın kendi kendisi ile çetin bir mücadeleye girmesindeki temel sebep onun fazla duygusal bir yapıya sahip olmasıdır. Ağabeyi Aras'ın güçlü kişiliğine karşın pasif bir kişilik olan Tuna duygusal kişiliğinden dolayı kendisiyle yüzleşip iç dünyasındaki savaştan 
başarıyla çıkamaz. Olay örgüsünde toplumsal savaş ile Tuna'nın içsel savaşı birbirine paralel ilerler. Bazen de bu iki savaş birbiriyle çatışır. Yazar bu şekilde hem toplumun hem de bireyin dünyasında yaşanılan savaşı aynı paralelde sunarak bu savaşların yol açtığı olumsuzlukları göstermeye çalışır.

Tuna, bir "Salı sabahı" eline aldığı gazete haberlerinde dünyanın her yerinde yaşanan terör olayları ve ölüm haberleri ile irkilir. Okuduğu bu haberlerde hep terör ve vahşet vardır.

"'Cezayir'deki iç savaş yabancıları da yok ediyor. Yedi italyan denizcisi boğazları kesilerek öldürüldü.'

'Şiddetli bir iç savaşın yaşandığı Yemen'de Güneyliler Birleşik Yemen'den ayrıldıklarını açıkladılar.

\section{(...)}

'Dünyanın en büyük temerküz kampı diye tanımlanan Saraybosna, kuşatma altındaki 1000. Gününe yaklaşıyor. BM kaynaklarına göre bu süre içinde 1572'si çocuk, toplam 10068 kişi öldü.' "' (s. 12)

$\mathrm{Bu}$ iç savaşlardan birinin yaşandığı Türkiye'de, huzuru yeniden sağlamak için askere alınmalar başlamıştır. Tuna'yı askere almak için bir üsteğmen ve bir asker kapıya dayandığı anda o, bunun gerçek bir iç savaş mı, yoksa kişinin içsel savaşı mı olduğu konusunda kuşku duyar.

"Bunu bekliyordum, dedi Tuna, dalgın dalgın bakarak, 'Bunu bekliyordum... Yıllardır kuşkuyla bekliyordum... Çünkü dışarda birileri ölürken, hiçbirimizin 'iç'i temiz kalamazdı!"'(s. 17) 
Tuna'ya göre savaşlarla gelen ölümler dış dünyayı kirletirken, duyarlı insanlar da iç dünyalarında çektikleri ıstırap, korku ve kaygı ile iç dünyalarını kirletmektedirler. Savaştan ve savaşa gitmekten korkan Tuna, bu korkusundan dolayı savaşın gerçek olmadığını ve savaştan korkan bilinçaltının kendisine bir oyun oynadığını düşünür. Korkunun ve kaygının beslediği bu düşünce askerlerin kendisini evinden alıp götürdüğü andan evine dönene kadar devam eder. O, evinden alındığında üsteğmenin arkasında yürürken kendini tutuklanmış gibi hisseder. Korkunun gölgesinde yürüyen Tuna'nın iç dünyası adeta bir yangın yeri olur. Ülkede seferberlik ilan edilmiş ve birçok insan huzur ve düzeni sağlamak için yeniden askere çağrılmıştır. Ancak Tuna'nın bilinci böyle bir gerçeği yok saymaktadır. Tuna, kendisinin "iftiraya uğramış bir masum mu, yoksa gerçekten bir suçlu mu?" olduğu konusunda iç dünyasında "yeni bir iç tartışma"nın içine girmiştir. Onun, gerçeği bir kâbus sanmasının temel nedeni, savaşı kabullenememesidir. Böylece yazar bir toplumsal savaş ekseninde kişinin iç savaşının da önemli olduğunu sezdirmeye çalışır. Her iki savaşın yıkımları birbiriyle yarışır durumdadır.

Tuna, ülkedeki bu iç savaşa inanmadığından yaşadıklarının, savaştan korkan beyninin kendisine yaşattığı bir kâbus olduğunu düşünmektedir. Askere götürüldüğü sırada aynı arabaya binen ağabeyinin arkadaşı Musa'ya yaşananların bir kâbus olduğunu şöyle anlatır.

"'Bütün suç bende... Hepsini benim korkularım, benim savaştan, şiddetten nefretim yarattı... Sizler aslında yoksunuz... Bütün bunlar benim kâbusum ve şu anda buradaki halinizle bulunan sizler aslında gerçek değilsiniz!' diye çok üzülerek itiraf etti Tuna." (s. 28)

Tuna, evinden alındıktan sonra askerlerle beraber, neresi olduğu söylenmeyen; ancak Doğu'da olduğu tahmin edilen bir mekâna getirilir. Bu konuda sorduğu bütün sorulara çevresindekiler sessiz kalır. Aslında nerede olunduğunun pek 
önemi yoktur. Yüzbaşı Birol’a göre bulunulan "nazik koşullar nedeniyle" bunu açıklamak yarar getirmeyecektir ve önemli olanın kutsal vatan toprakları üzerinde olunmasıdır. Onların burada olmasının tek sebebi toplumdaki karışıklığı gidererek huzuru sağlamaktır. Arkadaşlarıyla birlikte kendisini savaşın ortasında bulan Tuna, bu savaş ortamında da gerçeklerden kaçarak iç dünyasındaki savaşı yaşamaya devam eder. Savaşın ağırığını taşıyamayan Tuna duyma yetisini bile bir anlığına kaybeder. Bu bağlamda Tuna'nın yaşadığı dış ve iç savaşın dehşeti bir şoka sebep olmuştur.

"Yerinden kalktı. Aptal aptal çevresindeki sessiz korku filmini izledi. Sanki gerçeğin tamamen dışına düşmüştü (Hangi gerçeğin?) Alacakaranlıkta ateş, kan ve insan acısı dolu bir yerde donmuş kalmış, öylece dikiliyordu." (s. 190)

Savaşın yıkımlarının en canlı tanığı olan Tuna, bu sırada arkadaşı Musa'nın yaralandığını fark eder. Arkadaşının acı çektiğini görünce bu savaşın sebebi olan ve yıllarca masum insanların ölümleri karşısında susan kişilere nefret kusar. Tuna, bu iç karışıklıkta insanı öldüren herkesi; insan kılığındaki caniler, "çocuk kasapları, kan emiciler" olarak nitelendirir. Onun, "Hangi din, hangi millet cinayet işleyerek yücelmiştir ha!" (s. 191) şeklindeki söylemi savaşı hiçbir boyutta kabul etmeyen bir aydın tavrı içermektedir. Tuna, "Allah'ın belası savaş" diye lanet yağdırdığı iç savaş konusunda ise bütün toplumu suçlar. Bu savaşın neden yaşandığı ve kimsenin neden sorgulamadığı konusundaki sözlerine ise ironi hakimdir.

"Nasılsa bu ülkede doğanlar hep beklerler ve sabrederler zaten... Yüzyıllardır... Allah kerim! Anlarsınız ya! Tevekkül şart! Siz parmağınızı kıpırdatmayın, susun ve bekleyin! Allah kerim. Devlet Baba, Toprak Ana! Ohh! Bekleyin!"(s.239)

Bu savaşta Tuna'nın çevresinde tanık oldukları, onun iç dünyasındaki savaşın gittikçe şiddetlenmesine neden olur. Yaralı arkadaşı Musa'ya yardım eden o 
yöre insanlarından biri olan Hatice Hanım ve çocuklarının yaşadıkları, bu savaşın toplumda da karşılık bulmadığını gösterir. Hatice Hanım’ın çocukları Ali ve Lütfü ellerinde tabancalarla nöbet tutmaktadırlar. Ali ve Lütfi'nin çocukluklarını ellerinden alan bu savaş, onların hiç istemediği bir durumdur. Tuna bu evden ayrılırken yöre insanlarının da bu savaşı hiç istemediği, Musa ile yapılan diyaloglara şöyle yansır:

" 'Söyle Ali'ye, benim tüfeğim boştu.' dedi.

'Ali'nin tabancası da,' dedi Musa gülerek, 'Anaları hepsini boşaltmış!' "(s. 324)

Hatice Hanım'ın evinden ayrılan Tuna bir süre sonra bu savaşı asıl destekleyen kişilerin eline esir düşer. Terör örgütündeki kişilerce dövülen Tuna, bir yandan bu insanların kıyım yapmasındaki nedenleri zihninde sorgularken bir yandan da hala yaşadıklarının gerçek mi hayal mi olduğu ayrımını yapmaya devam etmektedir.

"Bu insanları bu kadar öfke ve kine sürükleyecek ne yaptığını düşünecek durumda değildi, içi çekiliyor, acıdan çıldıracak gibi hissediyordu.

'Delirmişsiniz siz!' diye bağırdı. 'insan değilsiniz siz!'

Sert bir cisimle kollarına ve göğsüne vurduklarını hissettiğinde artık acı duymadığını sandı. Ağzından akan ılık şeyin kan olduğunu düşündüğünde, artık onu kan tutmadığını anımsadı.

'Rüyamda ölüyorum,' diye düşündü. Midesi bulanıyordu, gözleri kararmıştı.

'Bu kadar nefret ve şiddet nasıl sığar insan bedenine?' diye bağırdı. Sesi çıkmadı." (s. 327) 
Tuna, bu tutsaklığı sırasında kendisi gibi orada tutsak olan Yüzbaşı Birol’e Orwell'in romanından geçen bir ifadeyi okur. Bu ifadede savaşın toplumlar içinde nasıl yayıldığı, kötülüğün her dönemde, her yerde nasıl var olduğu ve desteklendiği vurgusu hakimdir.

"'Yavaş yavaş, usul usul birikiyor kötülük...' diye fısıldadı Tuna. 'Toplumun bölünmesi, gammazlığın özendirilmesi, mafya, gizli örgütler, teröristler, tarikat tüccarları her yerde, her ülkede yerleşik düzene geçiyorlar. Gündüzleri normal insan kılığında dolaşan komşu erkekler, bir akşam bir maç sonrasında gözü dönmüş katil holiganlara dönüşüyorlar... Bir daha Nazi vahşeti yaşamayız diye inanırken, Bosna'da bebekleri kesiyor Avrupalı faşistler!...Orwell'ın romanında bunlar..."' (s. 330)

Yüzbaşı Birol'u şehit eden terör örgütünün elinden arkadaşı Sefer'in yardımıyla kurtulan Tuna'nın kendisiyle mücadelesi devam eder. O, bunların hepsinin bilincinin kendisine oynadığı bir oyun olduğunu düşünür; ancak bu oyundan bir türlü çıkamamaktadır. Tuna, kendi iç savaşında romanın başından sonuna kadar sorgulamalar yapar. En çok da aynı değerlerle bir arada yaşayan bir toplumun "kalabalık" haline gelerek "kitle psikolojisi"yle hareket etmesini sorgular. Dolayısıyla kitlelerin mantığının olmadığı Uzuner'in romanının vermek istediği mesajlardan biri olduğu söylenebilir. "Kitleye mensup insan medeniyet merdiveninden birçok basamak aşağı iner. Yalnız bulunduğu zaman terbiyeli, münevver biri iken, kitle halinde ise içgüdüleriyle hareket eden bir yaratığa dönüşmüştür. Artık bir vahşidir, sıradan insanın kendiliğinden gelişen şiddet eğilimlerine, merhametsizliğine, heyecanlarına ve kahramanlıkların sahiptir.(..) Kitle içindeki fert, rüzgârın istediği gibi kaldırdığı kum taneleri arasında, bir tek kum tanesidir."(Bon, 2014: 32). Kalabalıkların muhakeme ve düşünme yeteneğinden yoksun olması, onların yalnızca yıkıcı kuvvete sahip olmalarına neden olmuştur. Tuna, birlik olma ve bir arada olma fikrinden yanadır. 
Toplumun bazı kesimlerinin karmaşadan beslendiğimin farkında olan Tuna'ya göre, toplumda karmaşa ve düzensizliğe neden olan grupların duygularındaki abartı ve basitlik, eylemlerine de yansımıştır. Onlar "var olmak için öldüren canlılar!" haline dönüşmüşler; yaşatmak için değil, öldürmek için yaşayan bir canlı haline gelmişlerdir. Arkadaşı Sefer tarafından "birlik"e karşı olan ve kaos isteyen bir örgütün elinden yaralı olarak kurtarılan Tuna, hastabakıcı Hasan ile yaptığı konuşmada bu kadar vahşete yol açan teröristlerin bu eylemlerinin ardında yatan nedenleri sorgular.

"'Para vardır ardında hocam. Para hir şeyi yaptırır insana... Malum çiğ süt emmişiz hepimiz!'

'Ne parası yahu Hasan! Terörist bunlar; kin, nefret ve aşağılanmışlıkla yıkanmışlar! Artık ne kendilerinin, ne de başkalarının yaşamı bir anlam taşıyor onlar için...'

'Sen de pek safsın be hocam! Bütün bu tiröristlerin arkasında para, tonla kara para döner de sen hâlâ heçbi şeycik annamazsın ha!'"(s. 378)

Aslında Tuna'nın iç savaşı, Aras'ın öldüğü günde kalan bilincinin kendisine oynadığı bir oyundur. Aras'ın öldüğü gün iki önemli olay gerçekleşir. En önemli olay Aras'ın ölümüdür ve bu olayın etkisi ile yaşanılan bir diğer önemli olayın etkisi silinmiştir. O gün Aras, ölmeden önce Galatasaray’ın maçına gitmiştir. Ada ise telaşla onu beklemektedir. Tam bu sırada evi telaşlandıran haberi köşkün dadısı Cihan Teyze getirmiştir.

"O sırada Cihan Teyze korkudan gözleri fal taşı gibi açılmış olarak salona koşarak girdi.

'Gayrettepe taraflarında anarşistler bomba patlatmışlar! Hanımefendiciim, Aras'ın gittiği maç oralarda mıdır; Allah korusun!'”' (s. 262) 
Bütün ev halkının panik olduğu bu sırada Aras çıkagelir ve sonrasında kendisiyle birlikte maça giden arasın arkadaşları Musa ve Sefer'in iyi olduğunu söyleyerek Nesim'in de selamını Tuna'ya getirir. Musa, Sefer ve Nesim, Tuna iç savaşa götürüldüğünde asker olarak karşısına çıkacak ve Tuna o günden kalan bilinciyle baş etmeye çalışacaktır. Onlarla askerde bir araya geldiğinde Tuna bir taraftan sürekli bu yaşanılanların gerçek olmadığını dile getirerek kâbusundan çıkmaya çalışacak, bir taraftan da içinde büyüttüğü korkularıyla adım adım yüzleşecektir.

"'Bütün bunlar gerçek değil! Anlamıyor musunuz? Her şey aslında bir kâbus! Buradan çıkıp Ada'yı bulmalıyım! Onun bana ihtiyacı var, anlamıyor musunuz?' diye bağırıyordu Tuna hâlâ.

'Üstelik bu benim kâbusum ve sizler onun içinde oyuncularsınız. Endişelerim ve korkularımla sizleri beynimde ben yarattım. Hepiniz birer düş ürünü, birer hayalsiniz!" "(s.70)

Tuna, savaşa götürüldüğü "Salı sabahı" uyanmadan önce ilginç bir rüya görmüştür. Rüyasında gördükleri aslında kendi iç problemlerinin bir yansımasıdır. "Çünkü düş bir gizin açığa vurulması, ama eksik terimlerle açığa vurulmasıdır." (Freud, 1998: 23). Bu rüyada kendi "ben"ine yabancı bir "ben" vardır. Aynada yüzüne sürdüğü tıraş kremi bir maskeye dönüşür ve Tuna arkasında kendisine bakan birinin varlığıyla ürker; kendisine bakan ve gülümseyen bu Apollon baş hem kadın hem erkek özelliği taşımaktadır.

“Aynanın karşısına geçip, yüzüme tıraş kremi sürüyordum. Ama krem yüzüme yayılmıyor, aksine yapışıp kalıyordu. Birkaç kez deniyordum, denedikçe yüzümde beyaz bir maske oluşuyordu. Beyaz, soğuk ve katı.

Işste o sırada beliriyordu. Tam o anda. Boyu benden bir baş daha uzun. Tam arkamda duruyordu.(...) Bir Apollon başına benziyordu. Evet, evet, aynen öyle. 
Yine de ne kadın, ne erkek. Yani ilk bakışta bir erkek ama güzel yüzünde hem maskülin, hem de feminen çizgiler var." (s. 456)

Bir süre sonra Tuna, o ürktüğü ikinci kişinin de kendisi olduğunu fark eder. Gerçek "ben"i arkasından kendisine bakmaktadır. Tuna, bu rüya ile kendisini rahatsız eden bir sahteliğin, ası “ben”inden uzaklaşmış kişiliğinin farkına vararak uyanır. Tuna rüyasında kendisine ne kadar yabancılaşmış olduğunu hisseder. $\mathrm{O}$, yıllardır kendisinden uzaklaşmış, Ada ve Aras olarak yaşamını sürdürmüştür.

"Aynada gördüğüm o yabancı aslında 'ben'im!!!

Aslında 'ben' o başın içindeyim ama bunu bilmiyorum. 'Ben' aslında o yabancıyım!

'Ben' o'yum. O, 'ben'im.

Peki yıllardır aynada bakıp da 'ben' sandığım öbürü kim? Ben hangisiyim? 'Ben' hiç oldum mu?

Hayırr!! Ben varım! Ben hep vardım! Ben olacağım!!!" (s. 457)

Görüldüğü gibi Uzuner'in romanı da "Bütün zamanların bütün romanları, (gibi) ben'in bilmecesi üzerine eğilmiş(tir)." (Kundera, 2005: 35). Tuna, iç savaşa götürüldüğü o "Salı sabahı", rüyasında kendi yüzüne taktığı maskeyi fark eder. O, farkında olmadan çok uzaklaştığı gerçek "ben”ini bulmak için bir yolculuğa çıkar. İç savaşında doktora, kendisinden uzaklaşıp başka biri olmanın cezasını çektiğini, Tuna olarak değil de Ada ve Aras'ta yaşamış olmanın kendisini böyle bir kâbusa sürüklediğini şöyle anlatır:

" 'Onlarla; o ikisiyle öyle yakındım ki, kendimle ve zekâmla ilgili ne bir düşüncem, ne de şikâyetim oldu. Hiç! Asla! Aslını sorarsanız doktor, ben Aras ve Ada'yla 
büyümedim. Ben o iki mucize insanı sadece sevmekle de kalmadım. Ben onları yaşadım, ben onlar oldum, ben onların bedenlerinde de var oldum yıllar boyu! (...)

'Bir gün onlar artık yanımda olmadığında... o gün, evet böyle olmuş olmalı... tabi ya! Demek ki o sıralarda kendi zekâmı, kendi beynimi küçümsediğimin farkına varmış olmalıyım..." (s. 84)

Tuna'nın yaşadığı bu iç savaşın asıl nedeni pasif kişiliğidir. Toplumun gidişatını beğenmeyen ama onu değiştirecek cesarete de sahip olamayan Tuna için iç savaş kaçınılmazdır. Tuna, yaşadığı iç savaştan kurtulmak ister ancak o bunu başarabilecek güce sahip değildir. Oysa "Güçlülük, yürekli olmayı gerektirir. Yüreklilikse insanın kendi gerçekleriyle yüzleşebilmesini içerir." (Gençtan, 2014: 82) Tuna ne yazık ki pasif kişiliğinden dolayı "kendi iç savaşında" kendi gerçeklerini çok geç görecek ve korkularının üzerine giderek yavaş yavaş kendisini bulacaktır.

Tuna'nın iç savaşının en büyük nedeni toplumsal bir duyarlığa sahip olmasıdır. Kişilik olarak kendini bir koyun uysallığında gören Tuna, toplumsal duyarlığı keskin biridir. Toplumsal i̇ç savaşta seferberlik ilan edilince yedeklerin askere alımından dolayı Tuna'yı evinden almaya gelen üsteğmene söylediği sözler bu duyarlığın boyutunu gösterir. Onun duyarlığında eleştirel ve sorgulayıcılık hakimdir.

"Yani... kime karşı savaşıyoruz? Düşman kim? (...) Ama sorabilmeliyiz! Artık bizler sorabilmeliyiz!"' (s.17,26)

Tuna'nın iç dünyasındaki savaşta bir diğer çıkmazı toplumun içinde yaşayıp, onun sorunları karşısında susan kişiliklere karşı verdiği mücadeledir. Yukarıda bahsettiğimiz gibi Tuna aslında toplumsal olaylara duyarlı biri olduğundan kendi 
dünyasında, toplumun yaşadığı sorunlar karşısında eli kolu bağlı olmanın verdiği iç huzursuzlukla baş etmeye çalışmıştır. Tuna'ya göre aydınlığa koşan toplumların önündeki en büyük engel, yanlışlıklara karşı duyarsız kalmaktır. Toplumun bu yanlışığa müdahale etmemesi onu içten içe kemirmektedir. Tuna, elinden bir şey gelmemesi nedeniyle kendisinin de bu yanlışlara ortak olduğunu düşünür.

"Kendisine öğretenlerin içtenlikle bağlı kalarak ona aktardığı bütün değerler artık çökmüş, kıymetsiz, boş, saçma kavramlar olarak çöpe atılmıştı. Dostluk, aşk, sevgi, insanlık, eşitlik, vefa, sağduyu, affetmek, hoşgörü, özgürlük, güvenmek, inanmak, adil olmak, aklın yolları... Hepsi, hepsi kullanımdan kalkmış veya tamamen içerik değiştirmiş, üstelik ciddiye alınması toplumsal yasalarla yasaklanmış kavramlardı artık. Ve Tuna bu yüzden uzunca bir süredir içindeki savaşın kaçınılmaz olduğunu biliyor, kapısını çalmasını bekliyordu."(s. 48)

Dünyanın her yerinde insanların ölüyor olması ve bu duruma seyirci kalınması kendi onun ters bir davranıştır. 0 , dünyada yaşanan cehennemin karşısında sessiz kalmanın yanlış olduğunu iç savaşta arkadaşı Sefer'e anlatır. Tuna'ya göre yaşanan bu kadar acının, gözyaşının karşısında "susmak" en büyük tehlikedir.

"Bak Sefer, çevrene şöyle bir bak, şiddet, terör ve baskıdan canı yanmamış, canına tak etmemiş veya bezmemiş kimse kaldı mı? Ha? Söylesene? Sivil, asker, kadın, çocuk, bebek... Her gün insanlar ölüyor mu? Evet. Ve bizlerde bunu seyredip susuyor muyuz? Evet. Bak susuyorsun, bak bak, sen de susuyorsun! Gördün mü işte!.. Hepimiz susuyoruz zaten... Ben de sustum ama sustukça... sonunda başıma bu iş geldi!.." "(s. 93)

Tuna art arda okuduğu bu haberler karşısında öfke duysa da o, yapısı gereği bu savaşın karşısında duracak cesarette birisi değildir. Toplumsal iç savaşa götürülmeden önce bir taraftan bu kadar ölümden rahatsızlık duyan, bir 
taraftan da kan görmeye dahi dayanamayan bir Tuna vardır. Tuna'nın iç savaşında, yaşadığı bu çatışmanın da rolü büyüktür. Tuna, dünyanın her köşesinde yaşanan savaşların ve ölümlerin bir gün bizde de patlak vereceği korkuları içinde yaşamış, ancak bu korkularını hiç kimse ile paylaşmamıştır. Bu, onun iç dünyasındaki savaşın başka bir nedenidir. Zira Tuna arkadaşı Sefer ile konuşurken gerek savaş ile ilgili korkularını, gerekse de Ada'ya olan duygularını anlattıkça rahatlar.

"'Artık yakında bir iç savaş çıkar diye endişe içinde aylarca, yıllarca bekledim Sefer. Korkumun ve endişemin boyutlarını anlatamam sana.'

Sustu. Konuştukça açıldığını, rahatladığını şaşırarak fark ediyordu. Aylardır, hatta yıllardır bu konudaki endişelerini kimseyle paylaşmayışının yarattığı yük hafifliyor muydu?'"(s. 93)

"'Ada... O benim yaşamımda çok çok özel birisi... Üzerine titrediğim, çok sevdiğim, çok özlediğim bir insan... (...)

Ada'yla ilgili düşüncelerini ilk kez başkalarına açık edebiliyor olmasından şaşkın, ama müthiş ferahlamış kalakaldı koğuşun ortasında."(s. 97-98)

Yavaş yavaş kendisiyle yüzleşmeye başlayan Tuna, böylece bütün yaşadıklarının kendi ürettiği bir kâbus olduğunu iç savaşında Sefer'e anlatarak onu ikna etmeye çalışır. Bu, gerçeğin ağırlığını kabul edemeyen insanın kendine bir mazeret bulması veya kaçışıdır. Olayların kendisinin en sevmediği gün olan Salı günü başlamış olması onun bu korkularını daha çok büyümesine neden olmuştur. Birçok olumsuz olayın Salı günü gerçekleşmesi, bilincinin kendisine oynadığı bir oyun olduğunun düşünür.

" 'Ve bir sabah uyandım. Günlerden salıydı. (Bu benim en sıkıcı bulduğum gündür zaten!) Kapı çalındı. Iki asker kapıda bekliyordu. Beni askere aldılar. Seferberlik 
ilan edilmişti. Çok korkarak beklediğim şey tıpkı ama tıpkı düşündüğüm gibi başıma geldi! Anlıyor musun Sefer?'

Sefer hiç ses etmedi.

'Sence bu gerçek olabilir mi? Sırf ben düşledim diye, benim düşlediğim biçimde savaş çıkabilir mi Sefer?" "(s. 97-98)

Tuna aslında toplumun sorunlarına oldukça hassas birisidir; ancak bir şey yapamamanın verdiği iç huzursuzluk zihninde büyümüş ve kendisini sürekli rahatsız etmiştir. İnsani tükenişler ve savaşlarla gelen yıkımlar; insan sevgisiyle dolu Tuna'nın ruhuna bir karabasan gibi inmiştir.

Onun iç dünyasındaki savaştan bir türlü çıkamamasının nedenlerinden biri de iletişimsizlik ve yalnızlıktır. Tuna, bir bakıma her şeyin farkında olan, ama gördüğü sorunları düzeltemeyen, toplumla ve kendi dışındakilerle çatışma içinde olan bir aydını yansıtmaktadır. Kendisi gibi düşünen, olaylara kendisi gibi bakan tek kişi Ada'dır; ancak Ada, Aras'ı öldürdüğüne inanıldığı için bir "Salı sabahı" katil ilan edilmiştir ve konuşabileceği, kendisini anlayabilecek olan tek kişiyi de kaybetmiştir.

"'Benim gözüm açıldı Sefer. Dışarda; evimizin ve bedenimizin dışında sürekli birileri öldürülüyorken, öldürülen her insan için bizim de öldügümüzü anlamak ne çok zaman alıyormuş meğer!'

İçini çekti Tuna. Sefer de aynısını yaptı.

'Her ölüşümle bu kâbusu yeniden yaşamaya başladım. Şiddet ve çılgınlık artıyor, vurdumduymazlık çoğalıyordu. Bir iç savaş çıkacağı endişesi içimi kemiriyor, bu endişe giderek bütün sevinç ve umutlarımı gölgeliyordu... Kimseye bu 
korkularımı açamıyordum... Ya kaçıyor ya da abartığımı söyleyip, kafalarını kuma sokmaya devam ediyorlardı. Tek kişi vardı konuşacağım, o da...' " (s. 94)

"Salı sabahı" tıpkı Tuna gibi Ada'nın da kendi iç savaşının başladığı gündür. Çünkü aynı gün Tuna, savaş çıktığı haberlerini almadan önce Ada'nın, Aras'ı öldürdüğüne dair gazete haberlerini okumuştur. Tuna'nın savaşı toplumsal ve bireysel olarak iki yönlü olmasına karşın Ada'nın iç dünyasındaki savaş bireyseldir. Ada, Aras'ın öldüğü günde kalan bir “ben”le mücadeleye başlayacak ve iç dünyasında bir hesaplaşmaya gidecektir. Aras'ın ölümünden sonra Istanbul'dan, Kuzguncuktan hatta kendisinden kaçmaya çalışan Ada, yıllarca kendisini cezalandırarak aslında her an o trajik olaya kilitlenmiş bir beyinle yaşamını sürdürmüştür. Aras'ın öldüğü günden bu yana kendisine yüklediği suçun etkisinde kalan Ada bir "Salı sabahı" kendisine açılan mahkeme ile gerçeklerle yüzleşme fırsatı bulur. Böylece Ada, otuz altı yaşında bu savaşı kazanarak özgürlüğüne kavuşacak ve iç dünyasındaki savaştan Tuna'dan daha önce çıkacaktır. Ada, Tuna'ya yazdığı mektupta kendi iç hesaplaşma sürecini ve ruhunu yeniden özgür bırakmanın verdiği mutluluğu dile getirilmektedir:

"Mahkemenin sonlandığı gün, benim için çok önemliydi. Fena halde gecikerek anladım ki, Aras ölmüştü, ama ben yaşıyordum. Bu kadar basit bir gerçeği sahiden anlamak, bazen ne kadar uzun zaman alıyormuş meğer! Üstelik, suçum her ne ise, cezamı çekmiştim. Galiba artık geçmişimden özgürdüm.

Biliyor musun dün ne yaptım? Hani giderken Aras'ın iplerinden birbirine bağlayarak omzuma astığı 'converse'leri vardı ya, onları artık dolaptan çıkarttım ve kapıcıya verdim. (...) Tuna bunu başardım ben!"(s. 469)

İnsanın en büyük savaşı kendisiyle verdiği savaş̧ır. Ada, kendi iç savaşında önce mekân değiştirerek geçmişinden kurtulmaya çalışmış, daha sonra ise geçmişi hatırlatan "hatırlama nesneleri(ni)"(Assmann: 2017: 9) ortadan kaldırmıştır. Bu 
onun özgürleşmesindeki en büyük adımdır. Tuna'ya yazdığı mektupta özürlüğü kucaklamanın tadını şöyle haykırır:

"Biliyor musun dün ne yaptım? Hani giderken Aras'ın iplerinden birbirine bağlayarak omzuma astığı 'converse'leri vardı ya, onları artık dolaptan çıkarttım ve kapıcıya verdim. (...) Tuna bunu başardım ben!"(s. 469)

Romanda, toplumsal çatışmalar kahramanları huzursuz etse de toplumsal iç savaş onların önyargıları ve saplantılarıyla yüzleşmesini sağlamıştır. Toplumsal iç savaş sırasında kendi saplantılarından kurtularak iç dünyasındaki savaştan galip çıkanlardan biri de Musa'dır. Romanın ikinci derece işleve sahip kahramanlarından Musa, aşırı dindar tutumu ile kendisi gibi olmayan insanları "biz ve öteki" şeklinde konumlandıran biridir. Onun, Suları adlı alevi bir kıza olan aşkı, bu çıkmazdan kurtulmasını sağlar. Kısaca o, aşkın gücü ile önyargılarından kurtulur. Romanda yine ikinci derecede işleve sahip kahramanlardan Sefer de geleneğin kıskacındaki yanlış düşüncelerinin bir süre sonra farkına varır. Sefer, kız ve erkek çocuk ayrımı yapan ve erkek çocuğu daha fazla önemseyen biridir. O, kızını kaybedince bu yanlıştan acı bir tecrübeyle kurtulur. Tuna'nın annesinin Tuna'ya yazdığı mektup, Sefer'in yaşadığı acı tecrübeyi gözler önüne serer.

"Sefer, 'Teyzecim, ben kızımı oğullarımdan ayırırdım. Oğlanları daha çok severdim, Allah bana cezamı verdi!' diye ağlayıp, yüreğimi dağladı.

(...) 'Tuna'ya söyle anacığım, artık cinsiyet ayrımı yok, Sefer tövbekâr olmuş de!' diye ağladı."(s. 471)

İçerideki savaşın dış dünyadaki savaştan daha yıpratıcı olduğunun bir başka örneği roman kahramanlarından avukat Mutlu üzerinden metne yansır. Tuna'nın, iç savaş sırasında tanıştığı bir avukat olan Mutlu da toplumsal savaştan dolayı kendi içinde derin bir hesaplaşmanın içerisindedir. O da savaşa bir anlam 
verememektedir. Çünkü toplumsal iç savaş, avukat Mutlu'yu da insanlardan uzaklaştırıp kendi içine hapsetmiştir. Tuna'nın ona söylediği sözlere; savaşa ve vahşete karşı olan bir duyarlığın isyanı karışır. Tuna'nın sözleri; böyle bir savaşın gerçek olamayacağına, olsa olsa kâbus olabileceğine yönelik düşünceler savaşın saçmalığına ve mantıksızlığına inanmış bir bilinçaltının dışavurumudur.

"Mutlu, bak bunların tümü bir karabasan. Ben ve belki de sen uyandığında her şey düzelecek. Inan bana, inan ki, yeniden şiir okuyabilesin... Düşünsene bir, bu kadar aptalca biçimde birbirimizi doğramamı gerçek olabilir mi sence? Haa? Susuyorsun bak, olamaz değil mi? Hani Nazi dehşetinden ders almıştık? Hani uygarlaşmış, aya bile gitmiştik de teknoloji ve iletişimde bütün insanlık tarihinin en ileri dönemine gururla girmiştik? Ha? Bir terslik var bu işte değil mi? Var tabii..."(s. 463)

Eserde yazar, özellikle iç savaşın ele alındığı bölümlerde toplumun cehaletini temel sorun olarak metne yansıtır. Toplumsal iç savaşın sebepleri arasında yer alan cehalet, aydınlara göre toplumun yaşadığı kaosun ve gerilimlerin asıl nedenidir. İç savaş sırasında Tuna ve hastabakıcı Hasan arasında geçen ve bir aydın- halk çatışmasını yansıtan diyalogda toplumun en büyük cehaletinin; tevekkül, edilgen tavır ve tembellik olduğu sezdirilir. Farkındalık bilinci olan insanların yaşadığı iç mücadelelere karşın, yanlışları oluruna bırakan bir halkın cehaleti Hasan ile Tuna'nın bakış açılarındaki tezatla hissettirilmeye çalışılır.

" 'Ha bah sakın unutma amma...' diye ekledi Hastabakıcı Hasan çıkarken, 'şu Anadolu ermişlerinin vardır bi bildiği hocam... Sen bırak suyu aksın, su denize varsın!'

Gülümsedi. Tuna.

'Su hepimizi sürüklüyor Hasan...' diye mırıldandı. Hasan çoktan çıkmıştı. 
'Su hepimizi sürüklüyor...' diye esnedi.

Yine uykuya yenik düştü."(s. 88)

Görüldüğü gibi topluma hakim olan uyuşukluk, cehalet ve olumsuz hayat koşulları hiçbir şekilde sorgulanmamaktadır. Tuna, savaş sırasında Hatice Hanım'ın evinde onların yaşadığı yaşam tarzına bakarak böyle bir hayatı sorgusuzca kabul edişlerine, kendilerine verilenle yetinmelerine, başlarına gelen her şeyi sorgusuzca kabul etmelerine şaşırır. Toplumun en büyük tepkisi "beklemek"tir. Toplumun böyle bir yaşamı ses çıkarmadan kabullenmesinin temel nedeni yine cehalettir.

"Yaz sıcağının etkisiyle olacak ev ekşimiş çorba, idrar ve hasta insan kokuyor, fakat Tuna dışında öbürleri bundan rahatsız olmuş görünmüyorlardı. (...) Tuna'ya göre, onların yaşamının yalnızca üç ana elementi vardı: Korku içinde yaşamak, ellerindekiyle yetinmek ve beklemek! Kendini belli etmek, farklılıklarını göstermek ve daha fazlasını, daha iyisini istemek henüz bu topraklarda yasak ve günahtı... Ve tabii en önemlisi: Beklemek! Artık ne için ve neyi beklediklerini unutarak bekliyorlardı... Korkusuz, özgür ve bolluk içinde yaşama kavuşsalar ne yapacaklarını şaşıracak kadar uzun zamandır bekliyorlardı..." (s. 272-273)

Esere göre toplumun en büyük problemi cehalet, aydının ki ise sorumsuzluktur. Aydın, toplumun problemlerinin farkında olsa bile susarak çözümsüzlüğe katkı sunmaktadır. Bu suskunluk ve sorumsuzluk toplumun her kesiminin canı yakmaktadır. Seyirci kalmanın daha büyük bir tehlike olduğu yine Tuna'nın sorgulamalarında gerçekleşir.

"Bak Sefer, çevrene şöyle bir bak, şiddet, terör ve baskıdan canı yanmamış, canına tak etmemiş veya bezmemiş kimse kaldı mı? Ha? Söylesene? Sivil, asker, kadın, çocuk, bebek... Her gün insanlar ölüyor mu? Ve bizler de bunu seyredip 
susuyor muyuz? Evet. Bak susuyorsun, bak bak, sen de susuyorsun! Gördün mü işte!.. Hepimiz susuyoruz zaten..." (s. 93)

Yazar, eserinde toplumsal eleştirilerini aydın rolünü biçtiği kişiler yoluyla gerçekleştirir. Şair Doğan Gökay, Tuna'yla birlikte toplumsal sorunlar karşısında susmayan duyarlı ideal bir aydın tipini temsil eder. Romanın belki de en entelektüel figürü olan Şair Doğan Gökay, Tuna'ya yazdığı mektupta bütün toplumsal sıkıntıların kaynağını cehalet olarak değerlendirir. $O$, toplumumuzun geldiği noktadan tek kurtuluşun cehalete karşı savaşmak, azimle cehaletin üzerine yürümek gerektiği, ancak bu şekilde uygar bir toplumun oluşturulabileceğini savunur.

"Hayata düşman bütün cellatlara, yobazlara ve zorbalara inat hayattan zevk alıp, zevk alacak gençler yetiştireceksin. En azından onların yolunu açacaksın. (...) Cahiller korkak olur. Işıktan ve kültürden geçen yolda her gün daha uygar ve insani bir dünya kurmak için ancak bir avuç da olsak, bizler mücadele edeceğiz. Başka çaremiz yok."(s. 475)

Uzuner, böylece iç savaşın nedenlerinden birinin toplumsal cehalet olduğunu romandaki aydın rolünü üstlenen kişi aracılığıyla yaparak mesajını daha inandırıcı hale getirir.

Eserde toplumsal iç savaşın nedenlerinden biri de insanların birbirlerini "biz ve öteki" denkleminde konumlandırmaları olarak gösterilir. Yazar bu karşıtlığı yine, bu denklemin yaşandığı mekân olan Kuzguncuk aracılığıyla dile getirir. Kuzguncuk sakinleri, inançları ve yaşam tarzlarındaki farklılıklarıyla yüzyıllarca birlikte yaşayabilmenin mümkün olduğunu ortaya koymuş kişilerdir. Kuzguncuk, insanların yaşama sebebi olarak gördüğü mekânlardan biridir. Çünkü Kuzguncuk, her türlü farklılığın hiçe sayıldığı bir mekândır. 
"O zamanlar Yahudi, Ermeni ve Rumlar Kuzguncuk'un yerlileri sayılırmış. Müslüman ve Türk aile azınlıkta da olsa bir arada kaç-göç olmadan yaşar, birbirleriyle evlenebilirlermiş. Bir Müslüman'la evlenen gayrimüslim genellikle din değiştirir ama Kuzguncuk'a ait sayılan ortak kültürü bozmadan sürdürebilirmiş.(...) Nüfusun çeşitliliği ve coğrafyası açısından, hoşgörü ve iyi komşuluğun böylesine açık yaşanabildiği çok az istanbul semti vardır." (s. 36)

Romanda Kuzguncuk, farklı din ve ırkta insanların kaynaştığı, birlik ve beraberliğin en güzel şekilde yaşandığı mekânı temsil eder. Ancak yine de geçmişten gelen bazı düşünceler bu birliğe gölge düşürmektedir. Kuzguncuk'taki toplumsal sorunlar yine Tuna'nın gözünden sorgulanır.

"Marika en güzel kızdı ve Aras'a nasıl da hayrandı... Nesim de Marika'ya asılırdı ama Rumlar ve Yahudiler birbirleriyle evlenme geleneğine mi sahip değildi, neydi? Yoksa Ermenilerle Yahudiler mi evlenmezlerdi? Müslümanlar ne yapardı? Neydi sahi? Neydi aynı mahallenin çocuklarının arkadaşlığını serbest ama aşkını imkânsız kılan gelenekler böyle?” (s. 175)

Kuzguncukta eski kültürel alışkanlıklar devam etse de birlikte yaşama kültürü sorunsuz şekilde devam etmektedir. Kuzguncuk'ta yetişmesine rağmen sonraları dini görüşleri nedeni ile insanlar arasında ayrım yapan Musa, zamanla bu görüşlerinin yanlışlığını far keder. Musa'nın bu ayrımı, Tuna'nın bir süre ondan uzaklaşmasına neden olmuştur. Savaş ortamında Musa'nın yaralanması üzerine arkadaşının yardımına koşan Tuna'nın pişmanlığını dile getirir. Tuna hangi sebeple olursa olsun insanların birbirlerini "biz ve öteki" denkleminde konumlandırmalarının yanlışlığına dikkat çeker.

" 'Ölmeyeceksin Musa, sakın korkma arkadaşım. (...) Bak söz veriyorum artık bakkalına da uğrayacağım. Senin bana baskı yapmandan çekinmeden 
uğrayacağım. Birbirimizi kabul etmeyi öğrenene kadar sana geleceğim. Sakın ölme Musa, sakın..." (s. 191)

İç savaş sırasında Tuna, aslen Yahudi olan çocukluk arkadaşı Nesim ile karşılaşır. Tuna, dedesinin ilk eşi ve aslen Yahudi olan Rozita'nın kuzeninin torunu olan Nesim'in böyle bir savaşın içinde olmasına üzüldüğünden, onun bu ortamdan kurtulması adına, Jerusalem'e akrabalarının yanına niçin gitmediğini sorgular. Nesim bu sorgulamadaki insan ayrımını fark ederek öfkelenir. Onun öfkesi; aynı ortamda, aynı sevinç ve üzüntüleri yaşayarak "biz" olmak varken "sen" diyerek yapılan ayrımadır.

"'Gitmedim, çünkü senin gibi ben de buralıyım, burada doğdum ve burada yaşamak istiyorum! Allah kahretsin! Gitmedim, çünkü ben de bu ülke için vergi veriyor, çalışıyor ve burayı seviyorum! Duyuyor musun? Türkçe bağırıyorum sana! Öfkemi, aşkımı ve acımı ibranice değil, Türkçe bağırıyorum çünkü, geri kafalı adam!' (s. 153)

Nesim'e göre bu savaştan kurtulabilmek için tek koşul "birlik olmak"tır. "Birlik" ise ancak insanların birbirlerini olduğu gibi kabul etmesi ile mümkün olacaktır.

Eserde "birlik olmak" ve bir aradalık fikri "kültür" unsurları üzerinden de dile getirilir. Eserde bu fikrin en somut yansıması Karagöz oyunudur. Metinde Karagöz oyunu ile ilgili söylemler, metnin savunduğu tezlerden olan "birlik" olma düşüncesini içinde barındırır. Tuna'ya göre “Karagöz, Osmanlı’yı bize en iyi anlatan sembolleri taşır." (s.206). Karagöz oyunundaki oyuncuların sayısı, onlarca farklı kültürü bir arada yaşatan Osmanlının "en büyük dehası"nın bir yansımasıdır. Romanda Hayali İsmail'in bir gölge oyunundaki tiplerin zenginliği ile Osmanlı Devleti içinde yaşayan birçok etnik grubun geçmişte "birlik"te yaşayarak oluşturduğu zenginliğe dikkat çekilir. 
"'Anadolulu, Laz, Kastamonulu, Kayserili, Karamanlı, Eğinli, Harputlu, Kürt, Baba Himmet tiplemelerinin arkasında gerçek yatmaktadır çocuklar. Bunları okumayı öğrenirseniz, şifreleri daha kolay çözersiniz.' " (...) " 'Yahu, Birleşmiş Milletler gibiymiş bizim Karagöz oyunu da canım! Hay gözünü sevdiğimin memleketi be!' "' (s. 206-208)

Yazar roman boyunca savaş konusundaki söylemlerden sonra yer verdiği yukarıdaki "barış" söylemi ile, "birlik olmak" fikrini bütün toplumsal çatışmaları yok etmenin ön koşulu olarak sezdirmiş olur.

\section{SONUÇ}

Kumral Ada Mavi Tuna romanı aşk ve savaş olmak üzere iki ana izlek etrafında kurgulanır. Eserde insanın kendisiyle mücadelesinin, dış dünyadaki mücadelesinden daha zor olduğu eleştirel ve yer yer ironik bir üslupla ele alınır. Metinde savunulan teze göre toplumsal çatışmalar ve kutuplaşmalar kişisel ve toplumsal boyutta birçok probleme dönüşerek gerek toplumu gerekse bireyi çıkmaza sürüklemiştir. Bütün toplumsal iç savaşlar insan ruhunda çatışmalara, bölünmelere ve travmalara yol açar. Romanda özellikle güçlü kişilikten yoksun bireylerin bu tür olumsuzlukları daha derinden yaşadığı görülür. Toplumsal çatışmalar, bireyi kendisine yabancılaştırdığı gibi insanları "birlik"ten yoksun bırakarak zamanla kalabalıklara dönüşmesine neden olur. Bu ise toplum ve fert bağlamında birçok değer kayıplarıyla sonuçlanır. Metinde toplumsal çatışmaların kaynağını insanların sorgulamadan gerçekleşen eylemlerinde gören yazar, bu problemlerden çıkabilmenin yolu olarak "birlik" olmayı önerir. Yazar, romanda iç dünyadaki savaşın çıkış yolu olarak "aşk"ı, dışarıdaki savaştan kurtulmanın yolu olarak ise "birlik" olmayı görür.

İnsan anlamı olan bir varlıktır ve insanın en anlamlı tarafı sevme yetisine sahip olmasıdır. Aşk, insanoğlunun varoluşuna anlam katan bir değer olarak Buket 
Uzuner'in romanındaki en güçlü iki temadan biridir. Uzuner, romanında "aşkın bin bir çeşidi"nden birkaçını farklı aşk ilişkileriyle ele alır. Aşk, insan hayatını en çok anlamlandıran, yaşadığını en çok hissettiren değerlerden biri olarak metnin merkezinde yer alan unsurlardan biridir. Metne göre aşk, arayış ve sığınma özelliğiyle bazen insanın yaşamdaki ruhsal bir dayanağı, bazen de önyargılarından kurtulmasını sağlayan bir kılavuzdur. Roman, her insanın sevme potansiyeli ile doğduğu, duygusal yetmezliğin insanın iç dünyasında yaralar açabileceği gerçeğiyle bizi yüzleştiren bir eserdir.

\section{KAYNAKÇA}

Alberoni, F. (1990). Aşık olma ve aşk. Çev., Gül Çetinor. İstanbul: Düzlem Yayınları.

Assmann, J. (2015). Kültürel bellek. Çev., Ayşe Tekin. İstanbul: Ayrıntı Yayınları.

Bachelard, G. (2013). Mekânın poetikası. Çev., Alp Tümertekin. İstanbul: İthaki Yayınları,

Barthes, R. (2012). Bir aşk söyleminden parçalar. Çev., Tahsin Yücel. İstanbul: Metis Yayınları.

Bauman, Z. (2012). Ölümlülük, ölümsüzlük ve diğer hayat stratejileri. Çev., Nurgül Demirdöven. İstanbul: Ayrıntı Yayınları.

Bon, G. L. (2014). Kitleler psikolojisi. Çev., Hasan Can. Ankara: Tutku Yayınları.

Botton, A. (2005). Aşk üzerine. Çev., Ahu Antmen. İstanbul: Sel Yayıncılık.

Freud S. (1998). Psikanaliz üzerine. Çev., A. Avni Öneş. İstanbul: Say Yayınları. 
Fromm, E. (2008). Özgürlükten kaçış. Çev., Şemsa Yeğin. İstanbul: Payel Yayınları.

Gençtan E. (2014), Insan olmak. İstanbul: Metis Yayınları.

Gülsu, J. M. (2011). "Aşk-ı Esaret ya da Esaret-i Aşk”. Roman Kahramanları. Ekim/Aralık, Sayı 8, 159-161.

Kierkegaard, S. (2010). Ölümcül hastalık umutsuzluk. Çev., Mukadder Yakupoğlu. İstanbul: Doğu Batı Yayınları.

Korkmaz, F. (2018). Başlangıcından günümüze yeni türk şiirinde melankoli. Ankara: Grafiker Yayınları.

Kundera M. (2005). Roman sanatı. Çev., Aysel Bora. İstanbul: Can Yayınları.

Lupton, D. (2002). Duygusal yaşantı. Çev., Mustafa Cemal. İstanbul: Ayrıntı Yayınları.

Narlı M. (2012). Roman ne anlatır. Ankara: Akçağ Yayınları.

Phillips, A. (2017). Hep vaat hep vaat. Çev., F. Burak Aydar. İstanbul: Metis Yayınları.

Pines, A. M. (2003). Aşk ve kıskançlık. Çev., Canan Yönsel. İstanbul: Okuyan Us Yayıncılık.

Tosun N. (2014). Modern öykü kuramı. Ankara: Hece Yayınları.

Uzuner B. (2014). Kumral ada mavi tuna. İstanbul: Everest Yayınları. 


\section{EXTENDED ABSTRACT}

Buket Uzuner's novel Kumral Ada Mavi Tuna, published in 1997, has been translated into languages such as Italian, Greek and Hebrew in addition to Turkish. In the novel, which attracts attention with the substantiality of its discourses on love and war, a social civil war is depicted nested with multiple love stories. The uniqueness of the literary text is not in the subject but in the way it is fictionalized. Uzuner's novel is a unique work for its intensity in the parts where love is depicted and its mystery in the parts where war is narrated. The fact that each of the fictitious characters in Uzuner's novel express their opinions on the events and their worldviews as narrators is another feature that makes the novel unique.

The novel Kumral Ada Mavi Tuna is constructed around two main events. The first of these events is the love story between Ada-Tuna-Aras, and the other is the social civil war that occurs as a game played by Tuna's subconscious on himself. Both events take place within different time periods. The first event, in which the love story between Ada and Tuna is depicted, covers the time period of Tuna's life from age five to thirty four. The other main event, the social civil war, covers a time period of seven months. While time is reflected in the text with the flashback technique in the event concerning the love between Ada and Tuna, the parts about the social civil war develop chronologically. It is seen that the author included two different perspectives in the novel as a judge and a hero narrator and narrated their speech in accordance with their cultural levels. This success of the author in terms of novel technique increases the credibility in the narration.

In Kumral Ada Mavi Tuna, Buket Uzuner discusses the traumas caused in the human psyche by the social civil wars in Turkey. This social civil war, which is seen to be only a fear that Tuna's subconscious makes him experience, is based 
on the lifestyles, the desire for power and authority, and the idea of domination over different opinions, present in all societies. The question of "why people kill each other" is the main question of the text. The social civil war paved the way for the division of the society in terms of ethnicity, religion and sect, and at the same time, caused schisms in the human psyche and transformed into the inner struggle of the individual. Tuna, the protagonist, is the character who experiences the war the most both "internal"ly and "external"ly as he is the person who questions it the most. Tuna's questionings and criticisms towards the causes of the social war throughout the novel are the results of his intellectual attitude. According to Tuna, to whom the author lends her voice throughout the text, the main cause of social conflicts is the impulsive actions of people. According to him, the way out of social internal conflicts is to unite.

The inner world of man has been a perpetual subject of literature in every age. Love is reflected in the text in many works with the necessity of depicting the inner world of man. Love, which is one of the most powerful emotions in the inner world of man, is one of the two main themes in the novel Kumral Ada Mavi Tuna. The novel, which has a substantial list of characters, includes multiple love stories. The most notable love affair in the fictional plane of the novel is the love of two brothers named Tuna and Aras for a young girl. The development of this love story, which constitutes one of the two main events in the novel, carries traces of traditional narratives. In this love triangle, Tuna is in love with Ada while Ada and Aras are infatuated with each other. In the events where love and war are depicted side by side, the warmth and serenity of love and the coldness and ruthlessness of war constantly collide with each other. Although it makes them miserable, love enables the characters in the novel to overcome prejudices and move away from internal conflicts. 
The second event that is depicted in parallel with the love story in the novel is Tuna's recruitment for the military after the declaration of mobilization due to the civil war. Tuna, who is at war with his own consciousness, thinks that this war is not real after getting drafted for the second time and wants to get out of this nightmare as soon as possible. Tuna thinks that this war, the existence of which is unclear in the eyes of the reader, is a game played on him by his own consciousness but he is unable to get out of this game. The fact that the events started on Tuesday, his least favorite day, that it was happening exactly the way he imagined it, and that the two events he was afraid of the most happened on the same day appear to be proof that it is a game played on him by his own consciousness. The main reason why he is unable to get out of such a conflict is that he lacks a strong and willed personality.

Knowing and changing oneself, which is the most difficult thing to do for a human being, is a test faced by Tuna as well. Tuna was able to face his fears in a sense by finding himself and began defeating them.

Postmodern traces are observed intensely in the novel Kumral Ada Mavi Tuna, where war is handled both on a personal and a social level. In the work where reality and dream are intertwined, especially the parts in which the civil war is depicted are shaped around a "mystery" emerging from the conflict of reality and dream. 